\title{
TU/e EmonOWEN

\section{The structure of the cobalt sulfide phase in carbon-supported Co and Co-Mo sulfide catalysts as studied by EXAFS and XANES}

\section{Citation for published version (APA):}

Bouwens, S. M. A. M., Koningsberger, D. C., Beer, de, V. H. J., \& Prins, R. (1988). The structure of the cobalt sulfide phase in carbon-supported Co and Co-Mo sulfide catalysts as studied by EXAFS and XANES. Catalysis Letters, 1(1-3), 1-3. https://doi.org/10.1007/BF00765346

DOI:

10.1007/BF00765346

Document status and date:

Published: 01/01/1988

\section{Document Version:}

Publisher's PDF, also known as Version of Record (includes final page, issue and volume numbers)

\section{Please check the document version of this publication:}

- A submitted manuscript is the version of the article upon submission and before peer-review. There can be important differences between the submitted version and the official published version of record. People interested in the research are advised to contact the author for the final version of the publication, or visit the DOI to the publisher's website.

- The final author version and the galley proof are versions of the publication after peer review.

- The final published version features the final layout of the paper including the volume, issue and page numbers.

Link to publication

\footnotetext{
General rights

- You may freely distribute the URL identifying the publication in the public portal. follow below link for the End User Agreement:

www.tue.nl/taverne

\section{Take down policy}

If you believe that this document breaches copyright please contact us at:

openaccess@tue.nl

providing details and we will investigate your claim.
}

Copyright and moral rights for the publications made accessible in the public portal are retained by the authors and/or other copyright owners and it is a condition of accessing publications that users recognise and abide by the legal requirements associated with these rights.

- Users may download and print one copy of any publication from the public portal for the purpose of private study or research.

- You may not further distribute the material or use it for any profit-making activity or commercial gain

If the publication is distributed under the terms of Article $25 \mathrm{fa}$ of the Dutch Copyright Act, indicated by the "Taverne" license above, please 


\title{
THE STRUCTURE OF THE COBALT SULFIDE PHASE IN CARBON-SUPPORTED Co AND Co-Mo SULFIDE CATALYSTS AS STUDIED BY EXAFS AND XANES
}

\author{
S.M.A.M. BOUWENS * , D.C. KONINGSBERGER, V.H.J. de BEER \\ and R. PRINS * \\ Laboratory for Inorganic Chemistry and Catalysis, Eindhoven, University of Technology, P.O. Box 513, \\ $5600 \mathrm{MB}$ Eindhoven, The Netherlands
}

Received: 4 January 1988

\begin{abstract}
An X-ray absorption spectroscopy study has been carried out on a sulfided $\mathrm{Co} / \mathrm{C}$ and a $\mathrm{Co}-\mathrm{Mo} / \mathrm{C}$ catalyst, consisting of a fully sulfided $\mathrm{Co}-\mathrm{Mo}-\mathrm{S}$ phase. By comparing the EXAFS and XANES spectra of the catalysts with those of pure $\mathrm{Co}_{9} \mathrm{~S}_{8}$ and $\mathrm{CoS}_{2}$ reference compounds, it is shown that the cobalt ions in the Co-Mo-S phase have an octahedral-like sulfur coordination while the cobalt ions in the $\mathrm{Co} / \mathrm{C}$ catalyst have a larger fraction of octahedral cobalt than $\mathrm{Co}_{9} \mathrm{~S}_{8}$.
\end{abstract}

The role of the promoter $\mathrm{Co}$ and $\mathrm{Ni}$ ions in sulfided $\mathrm{Co}(\mathrm{Ni})-\mathrm{Mo}$ hydrodesulfurization (HDS) catalysts is a subject of great interest and numerous studies have been devoted to it. By the use of Mössbauer Emission Spectroscopy, Topsøe and coworkers showed that the cobalt atoms are situated at $\mathrm{MoS}_{2}$ crystallite edges in a so-called "Co-Mo-S" structure and that this structure governs almost completely the HDS activity [1-2]. Nevertheless, the exact structure of this phase or more precisely the location of the cobalt promoter is still an open question. Furthermore, the high specific activity of the $\mathrm{Co}-\mathrm{Mo}-\mathrm{S}$ structure is not understood. A different model was postulated by Duchet et al. [3] and by Vissers et al. [4] who observed a high activity for pure cobalt sulfide supported on activated carbon and hence explained the activity of a sulfided $\mathrm{Co}-\mathrm{Mo} / \mathrm{C}$ catalyst completely by the very high activity of the cobalt sites. Recently, Ledoux et al. [5] used solid state ${ }^{59} \mathrm{Co}$ NMR in a study of silica- and carbon-supported cobalt sulfide catalysts. In this study the authors showed that the promotion effect of cobalt was correlated with the concentration of cobalt sites with distorted tetrahedral symmetry, stabilized by so-called "rapid octahedral" cobalt atoms acting as a glue between the tetrahedral cobalt sites and the $\mathrm{MoS}_{2}$ phase. The active tetrahedral cobalt sites could, according to the authors, also be stabilized

* Technisch-Chemisches Laboratorium, ETH-Zentrum, 8092 Zürich, Switserland.

\# To whom correspondence should be addressed. 
without the presence of molybdenum by the small pores of the carbon support, confirming in this way the work of Vissers et al. [4]. The "rapid octahedral" cobalt atoms could not be related to the HDS activity [5]. Lately, however, Ledoux et al. proposed that these "rapid octahedral" cobalt atoms could be the origin of very active sites [6]. In this proposal the theory of Harris and Chianelli [7] was invoked. According to this theory, an electron transfer takes place from the "rapid octahedral" cobalt to the molybdenum ion, resulting in a strong activation of the three sulfur ions sandwiched between them.

In the present work we applied the EXAFS (Extended X-ray Absorption Fine Structure) and XANES (X-ray Absorption Near-Edge Structure) techniques to study the structure of the cobalt sulfide phase in a sulfided $\mathrm{Co} / \mathrm{C}$ and a $\mathrm{Co}-\mathrm{Mo} / \mathrm{C}$ catalyst. The carbon support used was a Norit RX3-extra, activated carbon $\left(S_{\mathrm{BET}}=1190 \mathrm{~m}^{2} \cdot \mathrm{g}^{-1}\right.$, pore volume $\left.=1.0 \mathrm{~cm}^{3} \cdot \mathrm{g}^{-1}\right)$. The Co $/ \mathrm{C}(4.1 \mathrm{wt} \%$ $\mathrm{Co})$ catalyst was prepared by aqueous pore volume impregnation with a solution of cobalt nitrate (Merck p.a.), while the promoted catalyst (1.5 wt\% Co, $7.7 \mathrm{wt} \%$ Mo) was obtained from Dr. J.A.R. van Veen. The latter catalyst was prepared in a special way, to ensure a maximum amount of the $\mathrm{Co}-\mathrm{Mo}-\mathrm{S}$ phase [8]. Mössbauer spectroscopy of this promoted catalyst clearly showed that only the Co-Mo-S phase was present after sulfiding [8] and furthermore that this $\mathrm{Co}-\mathrm{Mo}-\mathrm{S}$ is probably a Co-Mo-S type II phase, meaning a minor influence of active phase-support interaction $[8,9]$. The X-ray absorption measurements were carried out on freshly in situ sulfided catalysts at liquid nitrogen temperature at the SRS in Daresbury (EXAFS station 9.2). The sulfidation was carried out in a $10 \% \mathrm{H}_{2} \mathrm{~S}$ in $\mathrm{H}_{2}$ flow, flow rate $60 \mathrm{ml} \cdot \mathrm{min}^{-1}$ under atmospheric pressure, the temperature was increased linearly from 293 to $673 \mathrm{~K}\left(8.5 \mathrm{~K} \cdot \mathrm{min}^{-1}\right.$ for $\mathrm{Co} / \mathrm{C}, 2$ $\mathrm{K} \cdot \min ^{-1}$ for $\left.\mathrm{Co}-\mathrm{Mo} / \mathrm{C}\right)$ and kept constant at $673 \mathrm{~K}$ for $2 \mathrm{~h}(\mathrm{Co} / \mathrm{C})$ or $1 \mathrm{~h}$ (Co-Mo/C).

In this article a comparison is made between the $\mathrm{X}$-ray absorption spectra at the Co K-edge of the catalysts and those of pure $\mathrm{Co}_{9} \mathrm{~S}_{8}$ and $\mathrm{CoS}_{2}$ reference compounds. $\mathrm{Co}_{9} \mathrm{~S}_{8}$ was prepared by heating $\mathrm{Co}_{3} \mathrm{O}_{4}$ at $773 \mathrm{~K}$ in a gas stream of $\mathrm{H}_{2} \mathrm{~S}(10 \%)$ in $\mathrm{H}_{2}$ for $24 \mathrm{~h}$. The precursor $\mathrm{Co}_{3} \mathrm{O}_{4}$ was prepared by heating $\mathrm{Co}\left(\mathrm{NO}_{3}\right)_{2} \cdot 6 \mathrm{H}_{2} \mathrm{O}$ (Merck p.a.) in air at $873 \mathrm{~K}$ for $48 \mathrm{~h}$. $\mathrm{CoS}_{2}$ was prepared according to Morris et al. [10]. The purity of the $\mathrm{Co}_{9} \mathrm{~S}_{8}$ and $\mathrm{CoS}_{2}$ compounds was checked by means of X-ray diffraction. In bulk $\mathrm{Co}_{9} \mathrm{~S}_{8} 8$ cobalt atoms are tetrahedrally coordinated and 1 cobalt is octahedrally coordinated by sulfur. The Co-S coordination distance is in the range of 2.13 to $2.39 \AA$. The $\mathrm{CoS}_{2}$ structure consists of only octahedrally coordinated cobalt atoms.

In fig. 1 The Fourier-transformed EXAFS data of $\mathrm{Co}_{9} \mathrm{~S}_{8}, \mathrm{Co} / \mathrm{C}$ and $\mathrm{Co}-\mathrm{Mo} / \mathrm{C}$ are shown. The imaginary part of the Fourier-transform exhibits two peaks, the first one (at low $R$-value) can be ascribed to Co-S coordinations, the second one (at higher $R$-value) to the first Co-Co coordination (in $\mathrm{Co}_{9} \mathrm{~S}_{8}: R_{\mathrm{Co}-\mathrm{Co}}=2.50 \AA$ ). It is obvious in this figure that the Co-S peak amplitude increases in the order: $\mathrm{Co}_{9} \mathrm{~S}_{8}<\mathrm{Co} / \mathrm{C}<\mathrm{Co}-\mathrm{Mo} / \mathrm{C}$. Data-analysis (including the influence of 


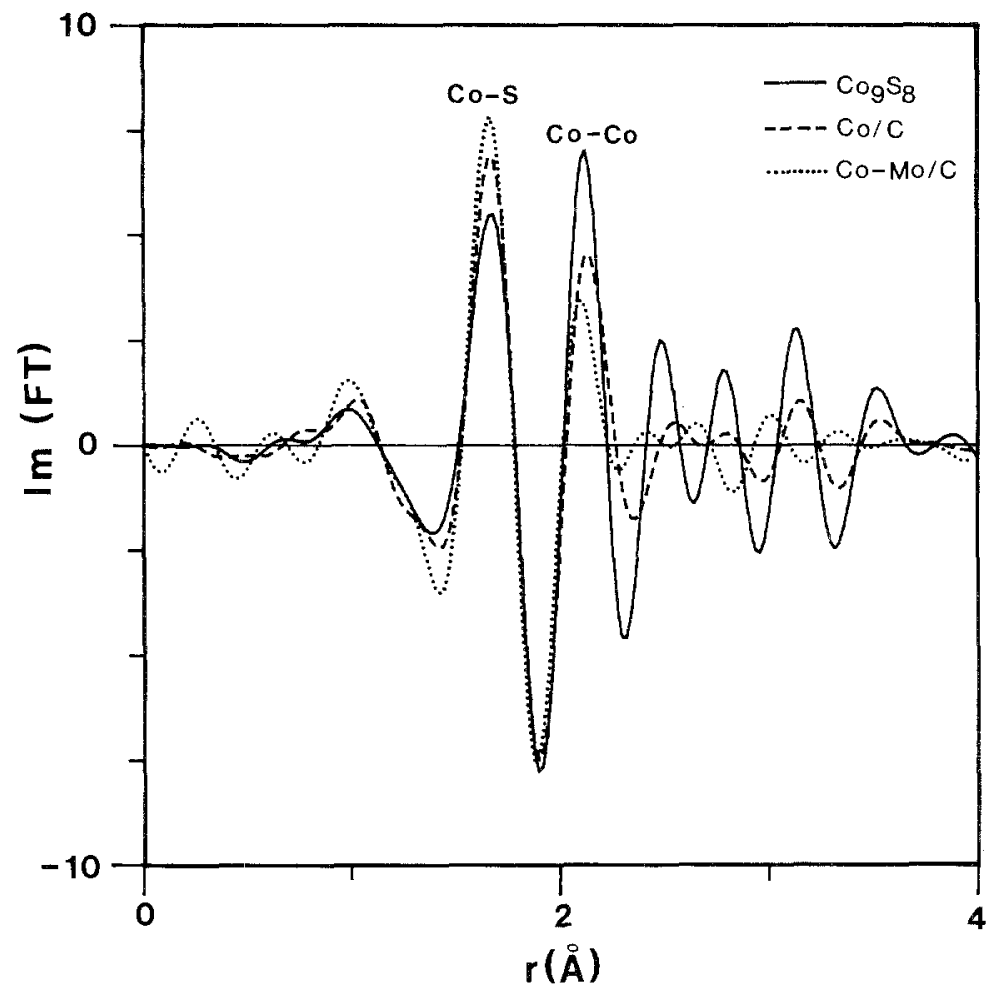

Fig. 1. Imaginary $k^{3}$-weighed Fourier-transforms $\left(\Delta k=3.0-10.9 \AA^{-1}\right)$ of the EXAFS data of $\mathrm{Co}_{9} \mathrm{~S}_{8}, \mathrm{Co} / \mathrm{C}$ and $\mathrm{Co}-\mathrm{Mo} / \mathrm{C}$.

Debye-Waller factors) reveals that the $\mathrm{Co}-\mathrm{S}$ coordination number increases in the same order [11]. From these spectral characteristics it is immediately clear that the cobalt ions in the catalysts have a higher sulfur coordination than those in $\mathrm{Co}_{9} \mathrm{~S}_{8}$ and furthermore, that this phenomenon is more pronounced when cobalt is present in a $\mathrm{Co}-\mathrm{Mo}-\mathrm{S}$ structure. Supplementary information on the cobalt coordination can be derived from the XANES region. The near-edge structure of the samples is shown in fig. 2. The spectra all show a weak absorption peak near threshold which has been identified as a $1 \mathrm{~s} \rightarrow 3 \mathrm{~d}$ transition $[12,13]$. This transition has been observed to be more intense in tetrahedral than in octahedral coordination of the absorbing atom [12], hence, it can be used as a measure of the coordination of the cobalt atoms. It can be seen in fig. 2 that the $1 \mathrm{~s} \rightarrow 3 \mathrm{~d}$ transition is most intense for $\mathrm{Co}_{9} \mathrm{~S}_{8}$ (consisting of $89 \%$ tetrahedral and $11 \%$ octahedral cobalt), whereas in $\mathrm{CoS}_{2}$ (consisting of $100 \%$ octahedral cobalt) its intensity is very small. The sulfided $\mathrm{Co} / \mathrm{C}$ catalyst shows an intensity between that of $\mathrm{Co}_{9} \mathrm{~S}_{8}$ and $\mathrm{CoS}_{2}$ suggesting a higher percentage of octahedral cobalt as present in $\mathrm{Co}_{9} \mathrm{~S}_{8}$. Very remarkably, the $\mathrm{Co}-\mathrm{Mo} / \mathrm{C}$ catalyst shows a very small intensity, comparable to the $\mathrm{CoS}_{2}$ compound, indicating that the cobalt ions in the $\mathrm{Co}-\mathrm{Mo}-\mathrm{S}$ phase have an octahedral-like sulfur coordination. The $1 \mathrm{~s} \rightarrow 3 \mathrm{~d}$ 


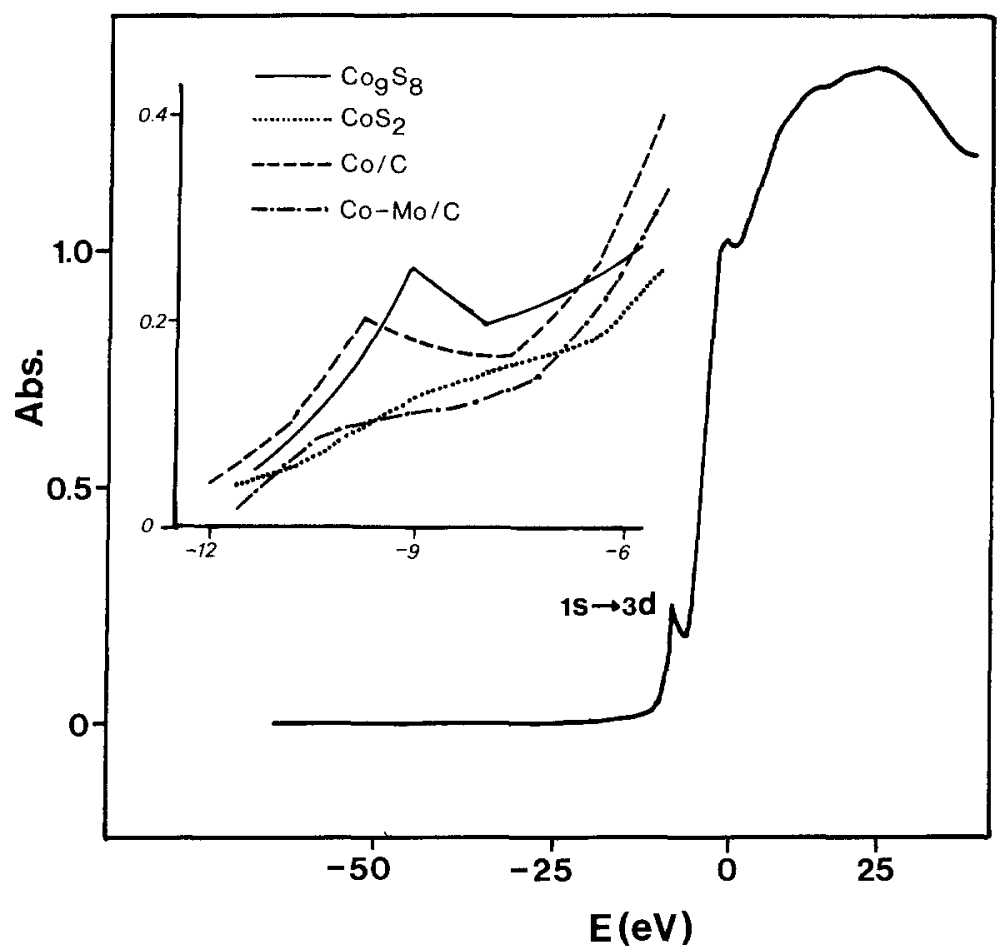

Fig. 2. XANES spectrum of $\mathrm{Co}_{9} \mathrm{~S}_{8}$. The expanded inset shows the $1 \mathrm{~s} \rightarrow 3 \mathrm{~d}$ transition of $\mathrm{Co}_{9} \mathrm{~S}_{8}$, $\mathrm{CoS}_{2}, \mathrm{Co} / \mathrm{C}$ and $\mathrm{Co}-\mathrm{Mo} / \mathrm{C}$.

near-edge feature is thus in complete agreement with the EXAFS spectra shown in fig. 1.

In view of our results, the proposal of Ledoux et al. of tetrahedral cobalt sites being responsible for the high HDS activity of cobalt-promoted molybdenum sulfide catalyst [5] must be rejected since we observe an octahedral-like coordination in the catalyst with the highest activity, the promoted catalyst. On the other hand, the other proposal of Ledoux et al. [6] that the "rapid octahedral" cobalt atoms might be the origin of very active sites, corresponds quite closely to our findings. From the observation that the structure of the cobalt sulfide phase in the $\mathrm{Co} / \mathrm{C}$ catalyst is not a specific $\mathrm{Co}_{9} \mathrm{~S}_{8}$ phase, as expected from thermodynamical considerations, it seems that the carbon carrier can modify the active cobalt sites.

This idea is not only in agreement with the theory of Ledoux et al. [5] but also with the work of Burch and Collins [14], who discussed the possible interaction between the nickel sulfide phase and an alumina, silica and carbon carrier material. The latter authors proposed that a metal sulfide - support interaction may alter the morphology or composition of the nickel sulfide phase. Finally, our findings are in line with the theory of Vissers et al. [4] that the cobalt phase in sulfided Co-Mo catalysts is the actual active phase. According to our EXAFS 
and XANES observations, the morphology of the cobalt phase in sulfided $\mathrm{Co} / \mathrm{C}$ corresponds closely to that in a Co-Mo/C catalyst: in both catalysts a high sulfur coordination of the cobalt atoms is present. In this respect it is also relevant to note that Vissers et al. [4] observed atomic S-to-Co ratios of 1.3 to 1.5 in XPS measurements on sulfided $\mathrm{Co} / \mathrm{C}$ catalysts, which values are much larger than the theoretical value of 0.89 for $\mathrm{Co}_{9} \mathrm{~S}_{8}$.

\section{Acknowledgements}

The authors would like to thank Dr. J.A.R. van Veen of the Shell laboratory (KSLA) in Amsterdam for providing a sample of $\mathrm{Co}-\mathrm{Mo} / \mathrm{C}$. The information in this paper is partly derived from a contract (EN3V-0009/NL) concluded with the European Economic Community.

\section{References}

[1] H. Topsøe, B.S. Clausen, R. Candia, C. Wivel and S. Mørup, J. Catal. 68 (1981) 433.

[2] C. Wivel, R. Candia, B.S. Clausen, S. Mørup and H. Topsøe, J. Catal. 68 (1981) 453.

[3] J.C. Duchet, E.M. van Oers, V.H.J. de Beer and R. Prins, J. Catal. 80 (1983) 386.

[4] J.P.R. Vissers, V.H.J. de Beer and R. Prins, J.C.S. Faraday Trans. I, 83 (1987) 2145.

[5] M.J. Ledoux, O. Michaux, G. Agostini and P. Panissod, J. Catal. 96 (1985) 189.

[6] M.J. Ledoux, J.C.S. Faraday Trans. I, 83 (1987) 2172.

[7] S. Harris and R.R. Chianelli, J. Catal. 98 (1986) 17.

[8] J.A.R. van Veen, E. Gerkema, A.M. van der kraan and A. Knoester, J.C.S. Chem. Commun. (1987) 1684.

[9] R. Candia, O. Sørensen, J. Villadsen, N.-Y. Topsøe, B.S. Clausen and H. Topsøe, Bull. Soc. Chim. Belg. 93 (1984) 763.

[10] B. Morris, V. Johnson and A. Wold, J. Phys. Chem. Solids 28 (1967) 1565.

[11] S.M.A.M. Bouwens, D.C. Koningsberger, V.H.J. de Beer and R. Prins, to be published.

[12] R.G. Shulman, Y. Yafet, P. Eisenberger and W.E. Blumberg, Proc. Natl. Acad. Sci. U.S.A. 73 (1976) 1384.

[13] R.B. Greegor, F.W. Lytle, R.L. Chin and D.M. Hercules, J. Phys. Chem. 85 (1981) 1232.

[14] R. Burch and A. Collins, J. Catal. 97 (1986) 385. 